\title{
The benefits of information system of water pollution at Bedadung river towards oral and dental health of the community
}

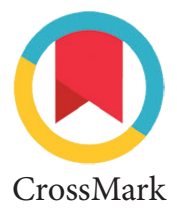

\author{
Heru Ernanda ${ }^{1}$, Zahreni Hamzah2 ${ }^{2 *}$, Dyah I. Setyowati ${ }^{3}$, Ary TW. Handayani ${ }^{4}$, \\ Tecky Indriana ${ }^{2}$
}

\section{Abstract}

Objective: The purpose of creating the river water pollution information systems related to oral and dental health community is to facilitate the analysis of diseases caused by water pollution.

Material and Methods: The environment-based health management information system based on GIS is based on real data of Bedadung River-Jember Regency, East Java, Indonesia includes the location of the dumping points, photo dumping points, the area of garbage accumulation and tooth and mouth disorders that arise due to contamination of river water, which is associated with community dental and oral health data that taken by survey.
Results: Through the environmental health information system information can be displayed about the environment and the dental and oral status of the population around the Bedadung river. Conclusion: The use of the environment-based health management information system is very important to help support the government's decision to prevent the spread and severity of community diseases caused by river water pollution, reduce morbidity and mortality and reduce the burden of government financing to treat diseases and disability integrated in an integrated manner.

Keywords: Water pollution, Bedadung river, Oral and health community, Environment-based health management information system Cite this Article: Ernanda H, Hamzah Z, Setyowati DI, Handayani ATW, Indriana T. 2018. The benefits of information system of water pollution at Bedadung river towards oral and dental health of the community. Journal of Dentomaxillofacial Science 3(2): 91-95. D0I: 10.15562/jdmfs.v3i2.738

${ }^{1}$ Department of Agricultural Engineering, Faculty of Agricultural Technology, University of Jember, East Java, Indonesia

${ }^{2}$ Department of Biomedical Sciences, Faculty of Dentistry, University of Jember, East Java, Indonesia

${ }^{3}$ Department of Oral Medicine, Faculty of Dentistry, University of Jember, East Java, Indonesia ${ }^{4}$ Department of Public Health, Faculty of Dentistry, University of Jember, East Java, Indonesia

*Corresponding to:

Zahreni Hamzah, Department of Biomedical Sciences, Faculty of Dentistry, University of Jember, East Java, Indonesia

zahreni.fkg@unej.ac.id

Received: 17 May 2018

Revised: 17 May 2018

Accepted: 19 July 2018

Available online 1 August 2018

\section{Introduction}

Waste discharged into the river varies considerably, including domestic waste, agricultural waste (fertilizer, pesticides and insecticides), livestock waste and chemical/industrial waste. Based on estimates the average volume of waste generated from daily human activities is $0.5 \mathrm{~kg} /$ per capita/day. ${ }^{1}$ Some of the waste in the rivers is recyclable, but some is not, which would continue to accumulate. Waste that is not properly managed would result in increasing diseases, either general (infectious or degenerative) diseases or dental and oral diseases. ${ }^{2}$ This condition would get worse if it is not followed by an adequate waste management system.

Water is a very important natural resource for daily necessities and drinking. Safe drinkable water is essential to human health all around the world. ${ }^{3}$ Water pollution would change water quality and harm the environment and human health. ${ }^{4}$ Water is also a universal solvent, and could be a major source of infection. According to the WHO, $80 \%$ of diseases in humans are caused by water. Water for drinking in various countries does not meet WHO standards. ${ }^{5} 3.1 \%$ of people die from unhygienic and poor water quality. ${ }^{1,6}$ Based on the Ministry of Environment and Forestry report from 2017, 75\% of rivers in
Indonesia are heavily polluted which is primarily caused by domestic waste. ${ }^{7}$ This is caused by the absence of adequate water management of environment-based health information system information system. This system needs to be created, at least in Jember region, to integrate various interests of the community.

Mostly, the composition of waste varies from paper, organic materials, natural waste, plastic and Styrofoam, inorganic materials, clothes, glass, sanitary napkins, pampers, and more. Paper, organic materials, and natural waste components are the largest component of household waste, followed by plastic (poly-ethylene bag) and styrofoam.

Bedadung River is a big river in Jember, East Java, Indonesia. This river is 46.875 meters long and allows irrigating rice fields up to 93.000 hectares. The characteristics of this river are unique; it is easy to overflow in the rainy season and dry in the dry season. The number of residents in the watershed area increases every year. Consequently, the need of clean water also increases. On the other hand, the amount of waste is increasing from time to time. Bedadung watershed area receives a variety of pollutants, either pollutants that flow directly into the river or from distant sources. 
Effects of Water Pollution on Dental and Oral Diseases

Many residents might not understand or care about the hygiene of the river. They often dispose refuse into the river. ${ }^{8}$ They have not realized that water pollution could cause various diseases. ${ }^{9}$ Viruses and microorganisms contained in river could invade the human body when the immune system decreases. Diseases caused by water pollution varies, not only cause infections such as cholera, typhoid, and other diseases, such as gastroenteritis, diarrhoea, vomiting, skin problems, liver and kidney diseases, ${ }^{1,10,11}$ but also non-infectious diseases.

Noninfectious diseases are commonly caused by water pollutants that potentially cause non-contagious diseases, such as accelerating aging, immune deficiencies, uric acid, diabetes mellitus type- 2 and other metabolic syndromes, cancers, increasing the blood pressure and cardiovascular, neuroendocrine and behavioral disorders, reproductive disorders (abortion and low birth weight), growth disorders (tooth and mouth defects or malformation), acute poisoning and some diseases that are still not fully disclosed. Cadmium, cobalt, mercury, chlorinated organic, lead, and others components commonly cause the diseases. ${ }^{12-22}$

In addition to general health, water pollution also affects dental disease and the oral cavity. Oral health is known as an integral part of overall health. The good oral hygiene is shown by the ability of a person to perform basic human functions, such as chewing, swallowing, talking, singing and smiling. These functions are important in communicating

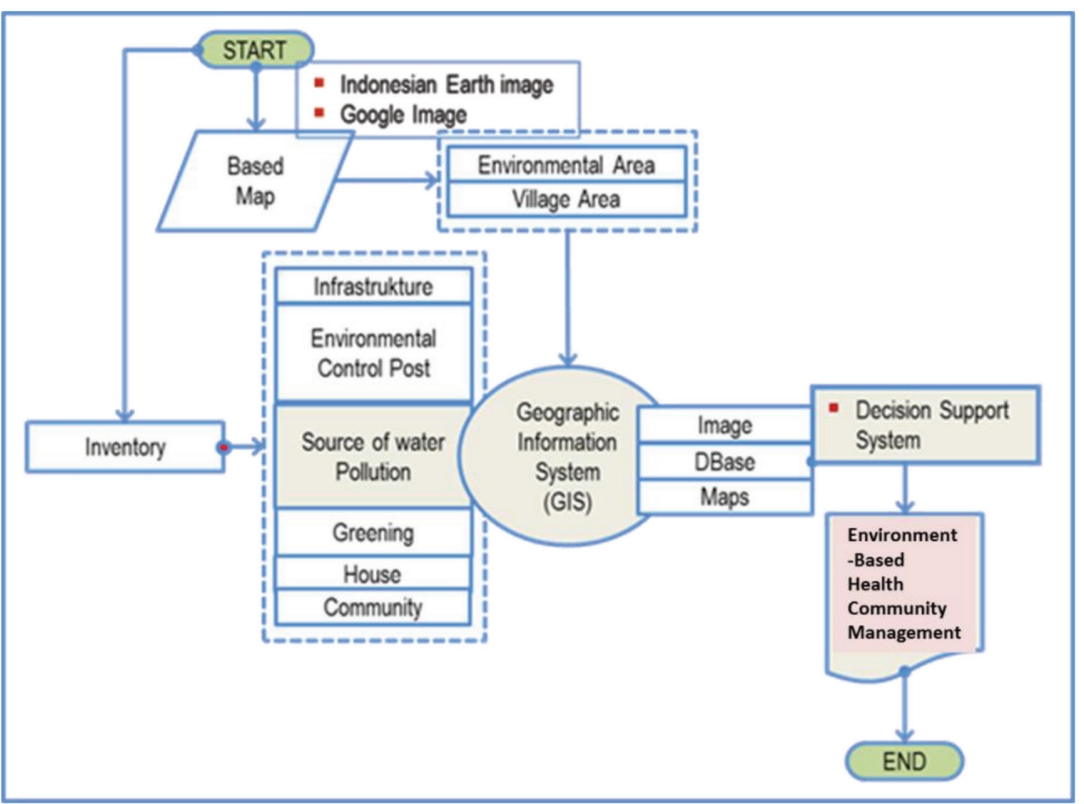

Figure 1 Structural design software of environment based health community management information system and interacting with others. Dental and oral health resulting from water contamination might be acute or chronic diseases, such as gingivitis, stomatitis, oral lesions, periodontal disease, cancer, dentomaxilofacial pain, oral and throat cancers, enamel structure damage, tooth loss, alveolar bone, cavity mucosa mouth, maxillofacial congenital defects, and various other tooth and mouth diseases.22 Fluoride consumption at moderate to high concentration in drinking water could cause damage to teeth and bones. Consumption in the long term and in large quantities could also lead to severe musculoskeletal problems. In severe cases, fluoride could cause changes in muscle, bone, and ligament structures, which could cause pain grievance. Water pollution could be caused by several chemical compounds, such as organic, inorganic and metallic materials ( $\mathrm{F}, \mathrm{Pb}, \mathrm{Fe}, \mathrm{Se})$ and several other chemical compounds.

Therefore, the creation of an integrated environment-based health program is very necessary to understand the condition of public health as well as the alleged cause of diseases from environmental factors. Thus, the prevention of disease could be carried out jointly with the management of the surrounding environment, such as the use of fertilizers, pesticides, insecticides and utilization of chemicals for agriculture and livestock.

Based on previous research, the author also mentioned that there is a relationship between dental and oral diseases such as diabetes, heart and lungs, diseases, stroke, respiratory illness, low birth weight, premature delivery and physical disability. In addition, the changes in the oral cavity often show early signs of health problems in other parts of the body, such as infectious diseases, immune disorders, nutritional deficiencies and cancer. Therefore, abnormalities in the oral cavity could be an early indicator of the onset of some other diseases in the body. ${ }^{23,24}$

Given the extent of the impact of water pollution on general health, dental health and oral cavity, water pollution should always be monitored so that the development of the disease would not develop to be worse and more widespread. In fact, the responsibility to control water pollution is the Central Government, Provincial Government, and Regency/Municipal Government as regulated in PP. 82 in 2001, which contains: determination of pollution load capacity; conducting inventory and identification to pollutant sources; establishing liquid waste requirements for applications in the ground; determining the requirements for disposal of liquid waste into water sources; monitoring water quality at water sources and monitoring other factors that lead the changes in water quality. Unfortunately, 


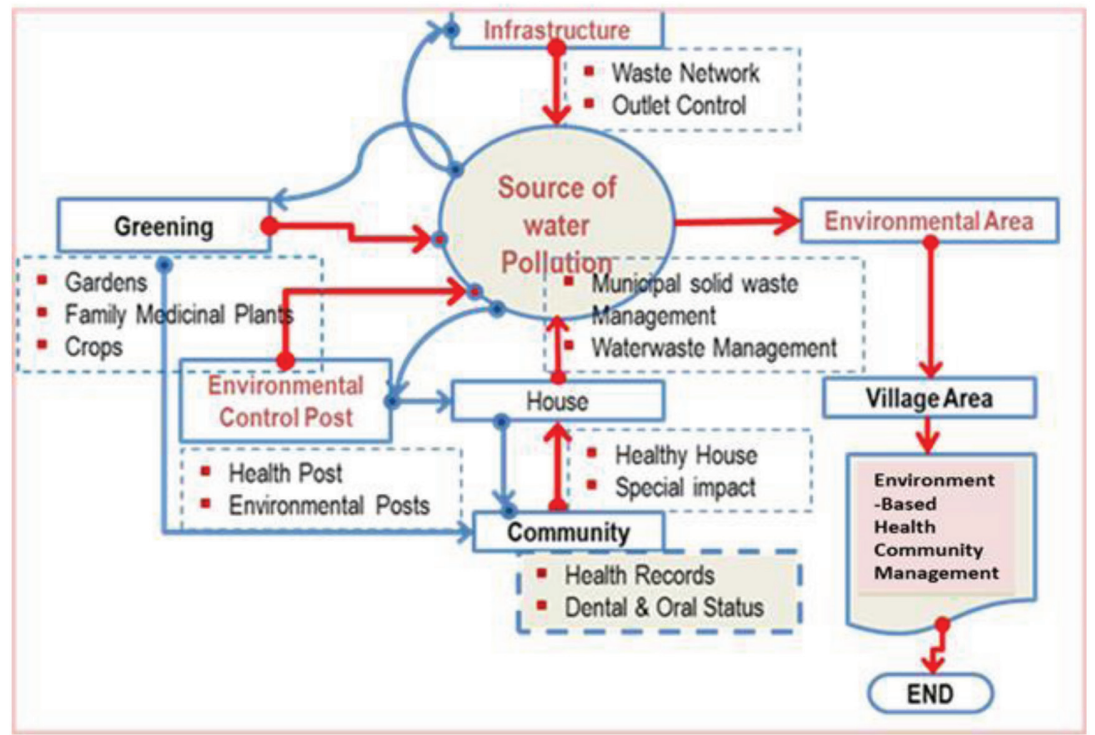

Figure 2 Functional design software of environment based health community management information system

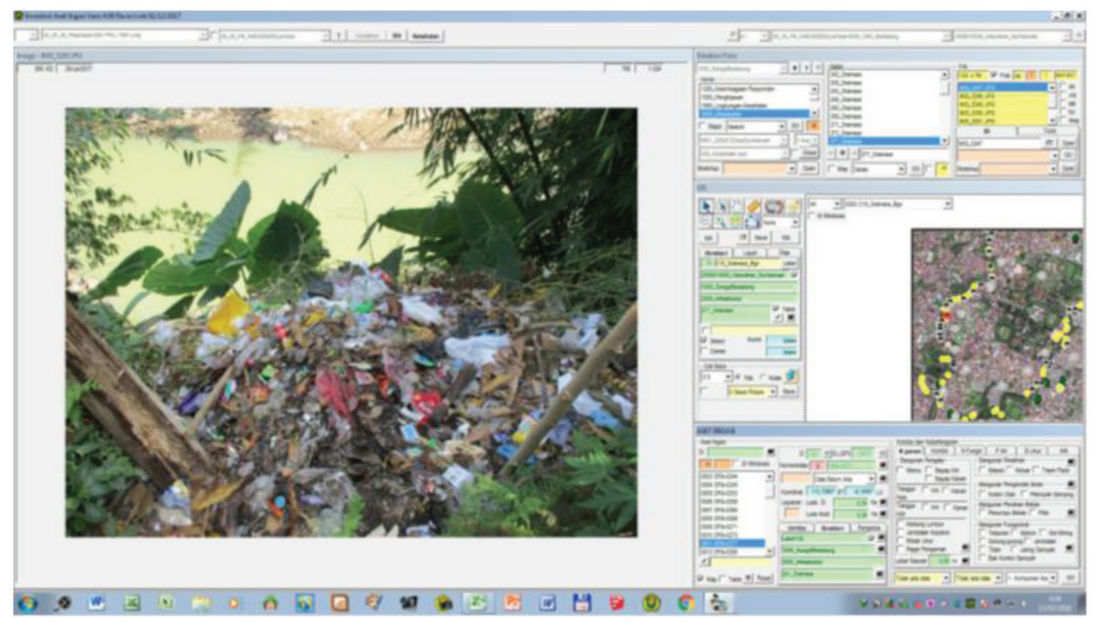

Figure 3 Display software environment based health community management information system

this regulation does not include the monitoring of the impact of water pollution on the health and oral health conditions of the community. ${ }^{25}$

This research aims to discover the benefits of using a database of environment-based health information on public health and including dental and mouth health of the community. It is expected that this program could be used for health service management planning and facilitate to overcome and prevent the spread of diseases in the Jember community, so as not to load health care funds, as well as reducing the morbidity and mortality of the population. Lately, it is known that many rivers in Indonesia are not hygiene anymore because of the amount of pollutants, both organic and inorganic, as waste products from human activities. Generally, river pollution is caused by bad habits and human negligence. People who less aware to maintain the environment, often dispose refuse in the river, even industrial waste is also sometimes disposed into the river. Rivers eventually become a giant refuse disposal site.

\section{Material and Methods System Information Design}

This environmental based health information system is an information system that encompasses spatial/ space-based data of infrastructure, environment, housing and health into an information system that could be used as a basis for building environment-based healthy communities. The information system is designed by utilizing the integration between a microsoft visual version 6.0 program and a map info version 11.50, which could be operated with paint shop image processing.

Measurement of waste is conducted by comparing the water quality standard parameters. The water quality standard is a measure of the limits or levels of living things, substances, energies or components that exist or must exist and/or pollutant elements that are tolerated in the water. The level of water quality condition that indicates the condition of contamination or good condition in a water source within a certain time, by comparing the water quality standard with the standard water quality standard (defined) is called the water quality status. Based on this criterion, the water classification shall be determined as follows: the condition of polluted water if the water quality does not meet the water quality standard; and good condition if water quality meets water quality standard. The status of water quality could then be used in the water pollution control information system database.

\section{Structural Design}

Structurally, environment-based health information system is designed to interpret the results of a Global Positioning System (GPS) survey which is covering infrastructure, health, and the environment into the Indonesian Earth Fundamental Map (Bakorsotasn, 1996) and google image of the seven database structures, as in figure $1 .{ }^{26}$

\section{Functional Design}

The functionality of the environment-based health information system is designed with the role of each dbase as in follows: infrastructure dbase could be operated to monitor and limit the overflow of drainage channels to the river; the environmental controlling dbase post that consists of health post dbases the posts, (posyandu, puskemas and 
others) and environmental posts; dbase Pollution source is a potential pollution and pollution testing dbase based on East Java governor regulation no. 72 in 2013 about quality standard of waste-water for industry and/or other business activities, as well as plans and realizations of waste management, which is expected to monitor the impact on health; reforestation dbase is a dbase (parks, community forestry potential, etc) based on environmental, food and toga (family medicinal plants) utilization; home dbase is a healthy home dbase (public health service) and local cultural characteristics of local houses towards environment and health; the community dbase is a personal dbase of families that shows the occupational health level. This dbase consists of medical history and dental health status. The functional interaction is presented in figure 2 .

Health, dental and oral health data used (form from WHO 2013) ${ }^{27}$ and obtained from this system were used for the identification of public health in Jember region. Water pollution control dbase information system is an integrated application, where applications could be accessed or monitored directly by the Department of Health, Agriculture Agency, Ministry of Environment and Environment Agency.

\section{Results}

The use of the environment based health community management information system does not only monitor river pollution, it also monitors points of refuse disposal along the Bedadung river, Jember, East Java Indonesia figure 3 and determines the type and the amount of refuse that piled on each point obtained from the photo of waste pile. At the same time, the health representation of the community was shown. It's public health, dental, and oral health of the community data that were obtained based on a survey based on the form of WHO in 2013.

\section{Discussion}

In addition, the environment-based health information system management program could also display information of: housing health and home health conditions; public drinking water conditions; environmental sanitation; general health conditions and disease grievance that occur in the community (both individually or in the family); dental and oral health conditions that occur in the community; ${ }^{28}$ potential of family medicinal plants and how to manage waste.

The collected information is expected to predict the pattern of disease in the community earlier, so that the prevention and control of the disease could be conducted optimally. Thus, the public health service as the government link for the health sector in Jember region could arrange the public health development plan and could reduce the morbidity and mortality rate due to water pollution. In addition, the efforts to improve health and oral and dental health, not only through curative efforts in the field of dental health but it could be conducted in an integrated and sustainable also crosscutting prevention, such as agriculture, health, irrigation, public works, urban and environment hygiene, and urban planning.

\section{Conclusion}

The use of environment-based health community management information system is a very helpful program to support the government programs to prevent the spread and severity of illnesses suffered by the community due to river pollution as to reduce morbidity and mortality rate and reduce the load of government financing to treat diseases and disabilities in an integrated procedure. In addition, this program could also be used for the determination of water pollution in Bedadung river, Jember Regency, East Java-Indonesia, based on GIS and could be a guide to ascertain the level of water pollution that impact on sustainable public health.

\section{Acknowledgment}

The author would like to thank the Public Works Service and the Jember District Health Office who has supported the creation of the environmentbased health community management information system. The study did not receive any financial support.

\section{Conflict of Interest}

The authors report no conflict of interest.

\section{References}

1. Haseena M, Malik MF, Javed A, et al. Water pollution and human health. Environ Risk Assess Remediat 2017;1: 16-19.

2. Ruslinda Y, Indah S, Laylani W. Studi timbulan, komposisi dan karakteristik sampah domestik kota Bukittinggi. J UNAND 2012;9: 1-12.

3. Bibi S, Khan RL, Nazir R. et al. Heavy metal analysis in drinking water of Lakki Marwat District KPK, Pakis-tan. World App Sci J 2016;34: 15-19.

4. Briggs D. Environment pollution and the global burden of disease. British Med Bullet 2003;68: 1-24.

5. Khan N, Hussain ST, Saboor A, et al. Physicochemical investigation of the drinking water sources from Mardan, Khyber Pakhtunkhwa, Pakistan. Int J Physical Sci 2013;8: 1661-1671. 
6. Pawari MJ, Gawande S. Water pollution \& its consequence. Int J Eng Res \& General Sci 2015;3: 773-776.

7. Purwati SU, Aryantie MH. Profil masyarakat dan lingkungannya sebagai modal membangun peran serta masyarakat dalam upaya pencegahan pencemaran lingkungan. J Ecolab 2016;10: 58-69.

8. Chagas S. The new path of the oncology. Cancer Prev Curr Res J 2018;9: 150

9. Frahm KA, Waldman JK, Luthra S, et al. A comparison of the sexually dimorphic dexamethasone transcriptome in mouse cerebral cortical and hypothalamic embryonic neural stem cells. Mol Cell Endocrinol 2018;471: 22-32.

10. Halder JN, Islam MN. Water pollution and its impact on the human health. J Environment \& Human 2015;2: 36-46.

11. Kamble RM. Water pollution and public health issues in Kolhapur City in Maharashtra. Int J Sci and Res Public 2014;4: 1-6.

12. Gomez F, Corchuelo J, Curcio C, et al. SABE Colombia: Survey on health, well being and ageing in Colombia study design and protocol. Cur Gerontol \& Geriat Res 2016;2016: 7910205.

13. Sun $\mathrm{H}$, Wang N, Chen C, et al. Cadmium exposure and its association with serum uric acid and hyperurecemia. Sci Rep 2017;7: 550.

14. Perdana WY, Jacobus DJ. Bisphenol A (BPA) adalah Endocrine Disrupture chemicals (EDC) yang ber-peran sebagai agen diabeto-genik. CDK-244 2016;43: 706-711.

15. Lee DH, Steffes MW, Sjödin A, et al. Low dose of some persistent organic pollutants predicts type 2 diabetes: a nested case-control study. Environ Health Perspect 2010;118: 1235-1242.

16. Quagliariello V, Rossetti S, Cavaliere C, et al. Metabolic syndrome, endocrine disruptors and prostate cancer association: biochemical and pathophysiological evidences. Onco-target 2017;8: 30606-30616.

17. Burks H, Pashos N, Martin E, et al. Endocrine disruptors and the tumor microenvironment: a new paradigm in breast cancer biology. Mol Cell Endocrinol 2016;S0303-7207: 30508-30601

18. Lee HM, Hwang KA, Choi KC. Diverse pathways of epithelial mesenchymal transi-tion related with cancer pro-gression and metastasis and potensial effects of endocrine disrupting chemical on epith-lial mesenchymal transi-tion process. Mol Cell Endocrinol 2017;457: 103-113.
19. Zhang W, Liu QX, Lin JS. Prevenion from pollution of carcinogenic endocrine disrupting chemicals in water sources. Cancer Prev Curr Res J 2017;1: 111-117.

20. Donato M, Cernera G, Giovannelli P, et al. Recent advances on bisphenol and endocrine disruptor effect on human prostate cancer. Mol Cell Endocrinol 2017;457: 35-42.

21. Goncharov A, Bloom M, Pavuk M, et al. Blood pressure and hypertension in relation to levels of serum polychlorinated biphenyl in residents of annis-ton, alabama. J Hypertens 2010;28: 2053-2060.

22. Goncharov A, Haase RF, Santiago-Rivera A, et al. High serum PCBs are associated with elevation of serum lipids and cardiovascular disease in a native American population. Environ Res 2008;106: 226-239.

23. Castoldi AF, Johansson C, Onishchenko N, et al. Human developmental neurotoxicity of metalmercury: impact of variables and risk modifier. Regul Toxicol Pharmacol 2008;1: 201-214

24. Ndountse LT, Chan HM. Role of N-methyl-D-aspartate receptors in polychlorinated biphenyl mediated neuro-toxicity. Toxicol Lett 2009;184: 50-55.

25. Schell LM, Gallo MV, Denham M, et al. Relationship of thyroid hormone levels to levels of polychlorinated bis-phenyl. Environ Health Perspect 2008;116: 806-813.

26. Yan C-A, Zhang W, Zhang Z, et al. Assessment of water quality and. identification of polluted risky regions based on. Field Observations \& GIS in the Honghe River. Watershed, China. PLoS 1 2015;10: e30-35.

27. World Health Organization. Oral health surveys: basic methods. 5th edition. Switzerland: WHO Press, Geneva 27; 2013. p. 1-125.

28. Akbar FH, Anwar AI. The correlation between denture usage satisfactions on quality life of the elderly. J Dentomaxillofac Sci 2017;2: 100-104.

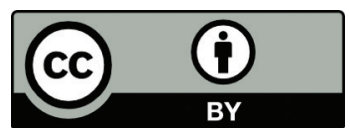

This work is licensed under a Creative Commons Attribution 